\title{
Best Management Practices (BMPs): Perimeter Borders ${ }^{\mathbf{1}}$
}

\author{
Vivek Sharma, Kati W. Migliaccio, Brian Boman, Jemy Hinton, and Kevin Hancock ${ }^{2}$
}

\section{Introduction}

Best management practices (BMPs) have been identified for different commodities and situations in many regions, including Florida. The Florida Department of Environmental Protection (FDEP) and the Florida Department of Agriculture and Consumer Services (FDACS) have identified conservation buffers such as perimeter border, filter strips, grassed waterways, and riparian buffers as BMPs to reduce the pollutants in surface water (FDACS 2015). This publication addresses perimeter borders as a BMP. The main aim is to provide basic information about perimeter borders along with design and maintenance criteria to agricultural clientele including producers, Extension agents, crop consultants and professionals, and state and local agencies.

The objective of a perimeter border is to provide a barrier using natural or synthetic material (e.g., native grasses, perennial vegetation, legumes and/or other forbs, etc.) that results in (i) less erosion and greater water infiltration, (ii) less sedimentation and increased protection of water quality, and (iii) food and shelter for wildlife and pollinators, which benefit both agricultural production and the environment.

\section{Description}

Soil erosion is a major concern in crop production that may result from wind or surface runoff. Soil erosion influences the productivity of agricultural systems by decreasing the amount of soil and its nutrient quality (Sullivan 2004). Not only does erosion influence the health of the crop by reducing the soil quality, but it can also contribute to water quality degradation. Soil particles that are eroded often contain phosphorus and other chemicals (such as nutrients, insecticides, and pesticides). As these particles and chemicals are transported from agricultural fields, they can enter water systems and have a negative environmental influence (Al-Kaisi et al. 2003). Perimeter borders reduce surface runoff volume, soil erosion, and water contamination through the settling of sediments, infiltration, and filtration (Schmitt et al. 1999), and their efficiency increases with the width of the perimeter border.

Perimeter borders may be used in vegetable and agronomic crop production (Figure 1) (FDACS 2015), specialty fruits and nut crops (FDACS 2011), nursery production (Figure 2) (FDACS 2014), and other agricultural production systems. Perimeter borders are most effective when established around an entire field. They can also be used as a connection to other buffers such as grassed waterways within and between fields, to provide efficient access for maintenance and crop production operations.

1. This document is AE439, one of a series of the Department of Agricultural and Biological Engineering, UF/IFAS Extension. Original publication date October 2008. Revised May 2021. Visit the EDIS website at https://edis.ifas.ufl.edu for the currently supported version of this publication.

2. Vivek Sharma, assistant professor, precision water management, Department of Agricultural and Biological Engineering; Kati W. Migliaccio, professor, Department of Agricultural and Biological Engineering; Brian Boman, professor emeritus, UF/IFAS Indian River Research and Education Center; Jemy Hinton, former member, BMP Implementation Team, UF/IFAS Gulf Coast REC; and Kevin Hancock, former member, BMP Implementation Team, UF/IFAS IRREC; UF/IFAS Extension, Gainesville, FL 32611.

The Institute of Food and Agricultural Sciences (IFAS) is an Equal Opportunity Institution authorized to provide research, educational information and other services

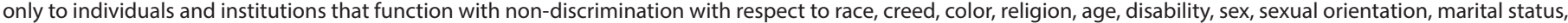

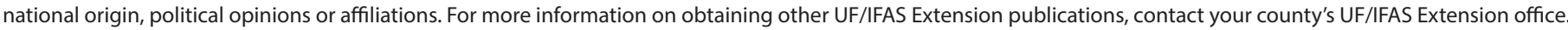
U.S. Department of Agriculture, UF/IFAS Extension Service, University of Florida, IFAS, Florida A \& M University Cooperative Extension Program, and Boards of County Commissioners Cooperating. Nick T. Place, dean for UF/IFAS Extension. 


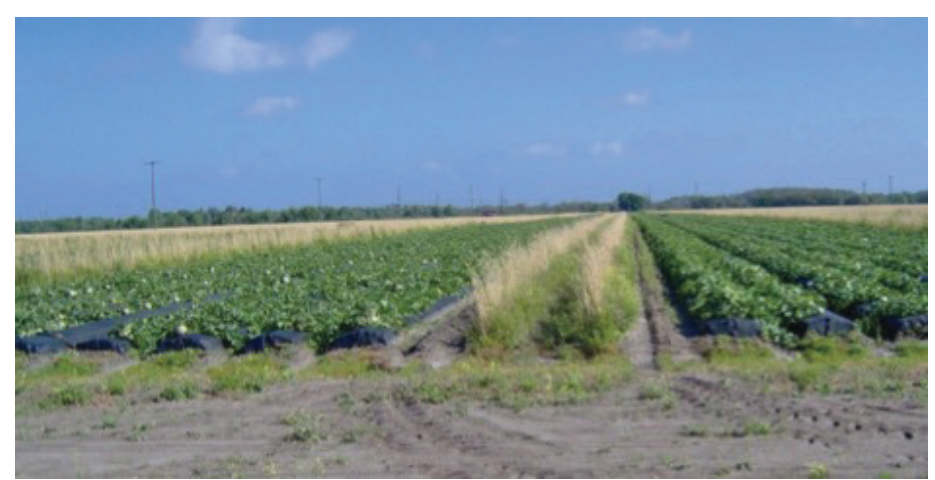

Figure 1. Vegetative growth placed among rows in a Florida melon field as a perimeter border.

Credits: J. W. Hinton

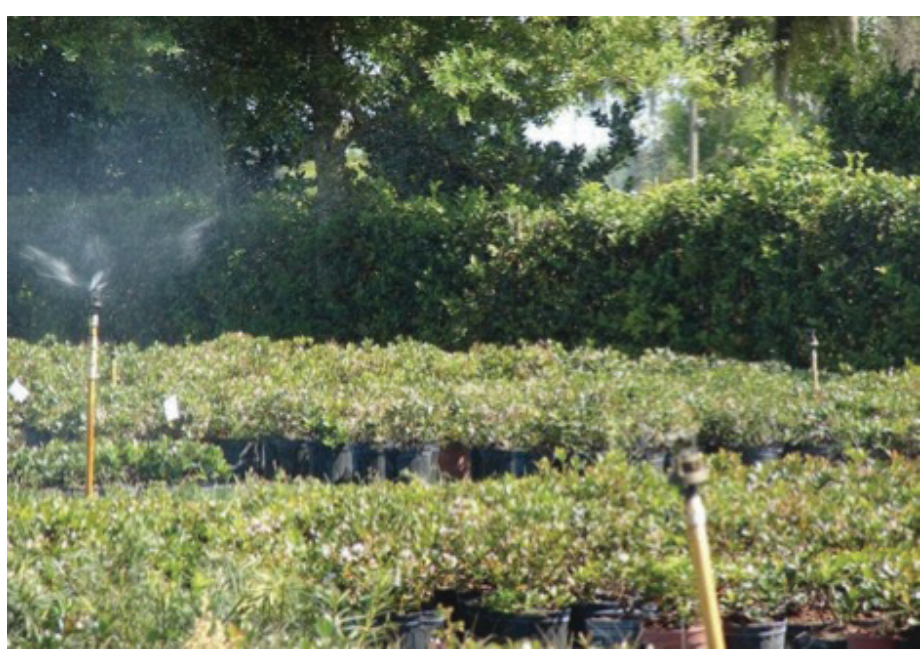

Figure 2. Vegetative hedge perimeter border in a Florida nursery. Credits: J. W. Hinton

\section{Perimeter Border Benefits}

The benefits of perimeter borders vary depending on the particular application. These benefits include:

1. Improved off-site water quality (Arora et al. 2003; BlancoCanqui et al. 2004);

2. Reduced erosion from wind and water (USDA NRCS 2016, Code 386);

3. Minimized plant blow-over and associated fertilizer spillage in nurseries (FDACS 2014);

\section{Reduced spray drift (Arora et al. 1996);}

5. Increased wildlife and bird habitat (Hoekstra and Hannam 2017; USDA NRCS 2016, Code 386);

6. Reduced harmful insect populations and a possible harbor for beneficial insects (Pierce and Milhollin 2008; USDA NRCS 2016, Code 386);

7. Improved air quality (USDA NRCS 2016, Code 386);
8. Enhanced aesthetics;

9. Increased carbon storage (Hoekstra and Hannam 2017);

10. Economic incentives (Pierce and Milhollin 2008).

\section{Perimeter Border Design and Maintenance}

The knowledge of two key parameters including border width and plant species is important for the proper design and maintenance of the perimeter borders. Optimum border width should be considered to meet the producer's production objectives and based on local design criteria. For example, border width should be enough to accommodate agricultural equipment turning, loading and unloading of equipment, and harvest operations, and at the same time provide water quality and sediment reduction benefits. Leaving a narrow border width ( 15 feet) can provide some benefits. However, a border width of 30 feet is generally recommended (USDA NRCS 2016, Code 386), which provides all the aforementioned benefits.

When selecting the vegetative material, it is important to select the plant species, grasses, or shrubs that accomplish the design objective (Figures 1 and 2). In the case of vegetative borders, the use of native species, permanent grass, legumes, and/or shrubs is encouraged to control wind and water erosion. If an annual plant is used, replanting will be necessary at critical times during the cropping cycle to ensure adequate soil and water protection (Pierce and Milhollin 2008). As per the state guidelines, plants listed in the state noxious weed list (https://www.fdacs.gov/ ezs3download/download/82900/2396262/Media/Files/ Plant-Industry-Files/Noxious_Weeds_Field_Guide.pdf) must be avoided. Other practices such as seedbed preparation, seeding rates, planting dates, seed depth, and fertility requirements will be consistent with local climatic and site conditions. However, it is important to remove any gullies and rills in the border area before the seedbed preparation. Another important feature is the plant root depth; the more established the rooting system, the greater the stabilization of surrounding soil. For more information on perimeter border design and seeding specification and recommendations, refer to Lenhart et al. (2017), Pierce and Milhollin (2008), and USDA NRCS (2016), Code 386.

Perimeter borders generally require some maintenance and, in some circumstances, may need irrigation to establish. Common maintenance of a vegetative border includes mowing or harvesting, trimming to maintain desired height, and scouting for pests. Weeding of harmful invasive 
species and/or noxious weeds is important to maintain the designed border width and density. Perimeter borders may become a habitat for wildlife, beneficial insects, and birds. The multiple uses of the perimeter border should be considered when conducting maintenance activities. Perimeter borders may not be appropriate if wildlife may not be a positive addition to the agricultural production area.

Over time, sediment accumulates along the border. Sediments should be removed before they reach a height that diverts runoff flow around the borders. Always inspect perimeter borders and repair any damage after a major storm event.

\section{Summary}

FDEP and FDACS indicate that nonpoint sources from agricultural and urban lands (runoff draining into lakes, rivers, wetlands, estuaries, and groundwater) are one of the greatest contributors to water pollution. Over the years, various BMPs have been developed to mitigate these impacts. Conservation buffers such as perimeter borders established at the edge, between, or around the field have been identified as a BMP to reduce pollutants in surface water. Well-designed and maintained perimeter borders can also provide conservation benefits including reduced soil and wind erosions, soil and water quality benefits, and increased wildlife, bird, and beneficial insect habitat. This publication provides basic information on perimeter borders along with design and maintenance criteria to the end user.

\section{References}

Al-Kaisi, M. M., M. Hanna, and M. Licht. 2003. Resources Conservation Practices: Soil Erosion \& Water Quality. Ames, IA: Iowa State University. http://www.extension.iastate.edu/ Publications/PM1901E.pdf

Arora, K., S. K. Mickelson, J. L. Baker, D. P. Tierney, and C. J. Peters. 1996. "Herbicide Retention by Vegetative Buffer Strips from Runoff under Natural Rainfall." Transactions of the ASAE 39(6): 2155-2162.

Arora, K., S. K. Mickelson, and J. L. Baker. 2003. "Effectiveness of Vegetated Buffer Strips in Reducing Pesticide Transport in Simulated Runoff." Transactions of the ASAE 46(3): 635.

Blanco-Canqui, H., C. J. Gantzer, S. H. Anderson, and E. E. Alberts. 2004. "Grass Barriers for Reduced Concentrated Flow Induced Soil and Nutrient Loss." Soil Science Society of America Journal 68(6): 1963-1972.
Florida Department of Agriculture and Consumer Sciences (FDACS). 2014. Water Quality/Quantity Best Management Practices for Florida Nurseries. https://www.fdacs.gov/ content/download/37570/file/nurseryBMP-lores.pdf

Florida Department of Agriculture and Consumer Sciences (FDACS). 2011. Water Quality/Quantity Best Management Practices for Florida Specialty Fruit and Nut Crops. https:// www.fdacs.gov/ezs3download/download/25409/516288/ Bmp_FloridaSpecialtyFruitNut2011.pdf

Florida Department of Agriculture and Consumer Sciences (FDACS). 2015. Water Quality/Quantity Best Management Practices for Florida Vegetable and Agronomic Crops. https://www.fdacs.gov/content/download/77230/file/ vegAgCropBMP-loRes.pdf

Hoekstra, P. F., and C. Hannam. 2017. "White Paper on Vegetative Buffers. A Report to the Agriculture and Agri-Food Canada Multi-Stakeholder Forum (Mitigation Working Group) for Neonicotinoids." https://seedinnovation.ca/wp-content/uploads/2017/11/Vegetative-BuffersWhitepaper.pdf

Lenhart, C., B. Gordon, J. Peterson, W. Eshenaur, L. Gifford, B. Wilson, J. Stamper, L. Krider, and N. Utt. 2017. Agricultural BMP Handbook for Minnesota, $2^{\text {nd }}$ Edition. St. Paul, MN: Department of Agriculture. https://wrl.mnpals. net/islandora/object/WRLrepository\%3A2955/datastream/ $\mathrm{PDF} /$ view

Pierce, R. A., B. White, D. T. Jones-Farrand, T. V. Dailey, and B. Carpenter. 2008. "Field Borders for Agronomic, Economic and Wildlife Benefits." University of Missouri Extension. https://extension.missouri.edu/publications/ g9421

Schmitt, T., M. G. Dosskey, and K. D. Hoagland. 1999. "Filter Strip Performance and Processes for Different Vegetation, Widths, and Contaminants." American Society of Agronomy, Crop Science Society of America, and Soil Science Society of America 28(5): 1479-1489.

Sullivan, P. 2004. "Sustainable Soil Management: Soils Systems Guide." National Center of Appropriate Technology. http://attra.ncat.org/attra-pub/PDF/soilmgmt.pdf

United States Department of Agriculture Natural Resources Conservation Service. 2016. "Conservation Practices Standard - Field Border. Code 386 (Ac)." https://www.nrcs. usda.gov/Internet/FSE_DOCUMENTS/stelprdb1241318. pdf 